\title{
Polluting utopia
}

\section{The idyllic reputation of a lost island community may not be wholly deserved.}

\section{Andy Meharg}

The remotest occupied island in the British Isles, the Outer Hebridean outlier Hirta in the St Kilda archipelago, has become symbolic of a utopia corrupted by modern, capitalist society. Originally a self-sufficient and self-governing community, the islanders changed their aspirations as soon as they had regular contact with outside culture in the nineteenth century. They yearned to leave their sea-girt, lonely home, and Hirta was completely abandoned in 1930. The death of the island community was immortalized in Michael Powell's 1937 film The Edge of the World.

The island has long commanded the fascination of the British public. It was the subject of one of the most remarkable, and earliest, of British travelogues, Martin Martin's A Description of the Western Islands of Scotland, circa 1695, and his later A Voyage to St Kilda. Martin travelled at the behest of the Royal Society, recording Gaelic culture before the disruption that followed the Jacobite rebellion of 1745 . Unlike most early documenters of remote cultures, Martin was of the people, a Gael from the Hebridean island of Skye. His book inspired, among others, Samuel Johnson's A Journey to the Western Isles of Scotland.

The extent of anthropological study of the small St Kildan community is unparallelled, and has spawned a vast literature in the past 300 years. The documenters of island life were captivated by a culture solely dependent on the exploitation of seabirds, which were harvested for food, oil and feathers. They were also entranced by the island's remoteness and apparent independence. The archipelago's owner extracted a yearly rent. The island was self-sufficient and had no cash economy. It had a 'parliament' that met every day to take democratic decisions affecting the life of the community. A rotation of land stewardship ensured fairness in resource allocation, like the "anarcho-syndicalist commune" of Monty Python and the Holy Grail. Many nineteenth- and twentieth-century chroniclers have described the island as a utopia, including John MacCulloch, who wrote of his 1815 visit: "If this island is not the Eutopia so long thought, where will it be found? Where is the land which has neither arms, money, law, physic, politics, nor taxes?"

that, although they are anthropomorphic, are based on sound science.

The other seven essays are on widely different topics, from Wendy Doniger on zoomorphism in Indian Sanskrit texts to Paul White on the experimental animal in Victorian Britain. Cheryce Kramer discusses the ways in which Tim Flach manipulates his photographs to change our perceptions of animals: for example, his photos of bats are printed so that the animals appear to be

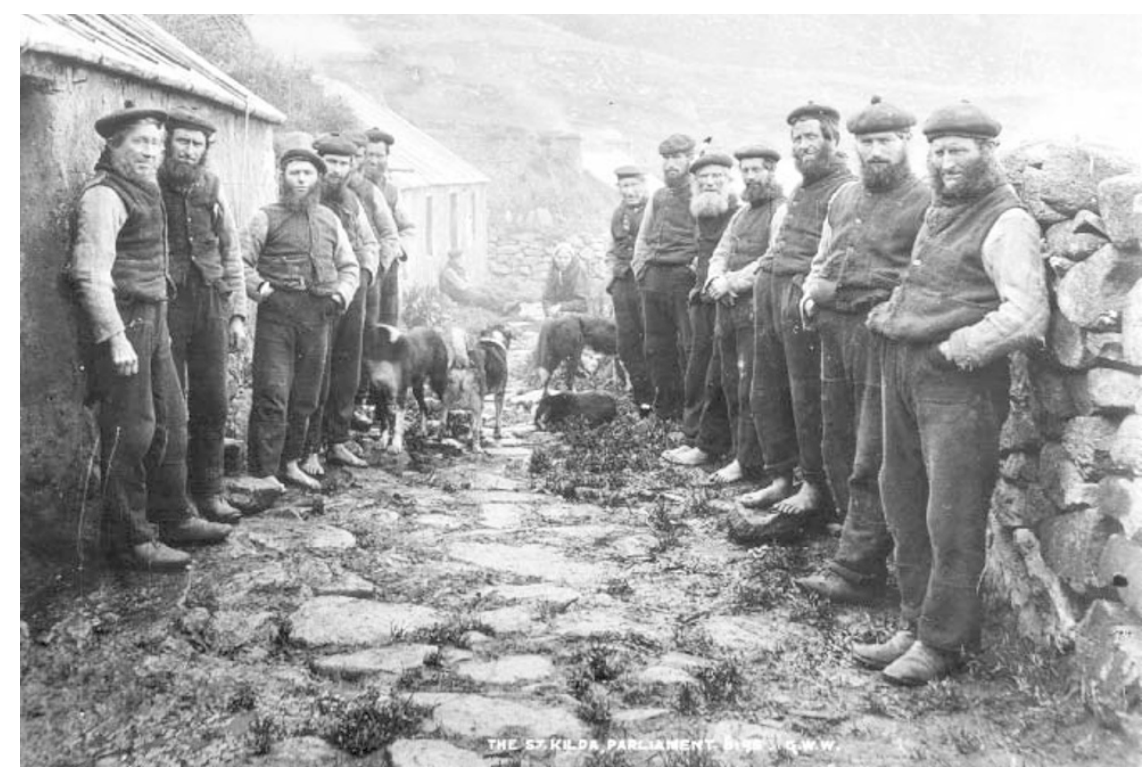

Paradise lost: the inhabitants of Hirta contaminated their island by overexploiting seabirds.

The Hirta community is now an iconic image for a devolved Scotland with a strong socialist tradition. The architect Enric Miralle's design for the new Scottish parliament drew inspiration from the St Kildan parliament, incorporating the forms of upturned keels of boats as a representation of the island's life.

But this utopia is a myth. The St Kildans' bird culture had severe effects on European seabird populations. Most notably, the islanders beat to death the last observed great auk in Britain, which they held to be a witch, in 1840, just before the global extinction of the species. My own research has thrown some light on the ecological balance of the island, showing that agronomic practices led to severe pollution of the arable land.

According to Martin, the St Kildans recycled all their wastes - faeces, peat ash, and bird guts and bones - applying them to their arable land as fertilizer. When I analysed these arable soils they were highly contaminated with lead, zinc and dioxins (Nature 421, 909-910; 2003). By analysing the lead isotopic composition of the arable soil, archaeological and modern seabird bones, and ancient peat ash from dwelling floors, I worked out that this pollution was coming from peat ash

standing upright, rather than hanging down, so they look like standing people. Sandra Mitchell asks: "What is the fate of anthropomorphism in contemporary science?" and argues that evidence is difficult to obtain, either way, for whether there are cognitive similarities between humans and animals. James Serpell writes about how thinking of animal companions in human terms is responsible for many of the benefits that their owners derive from them, such as the and bird bones in the compost stream. This pollution of arable soils is, to date, unique in terms of ancient settlements and was included in the case made to UNESCO (the United Nations Educational, Scientific and Cultural Organization) by the National Trust for Scotland (the archipelago's current owner) for extending St Kilda's World Heritage Site status for natural and marine environments to include the cultural landscape. The UNESCO committee will consider the proposal in June. Pollutant levels are so high, with lead and zinc concentrations in arable soils reaching $500 \mathrm{mg}$ per $\mathrm{kg}$, that they compare with the soils of Britain's most polluted industrial cities.

The pollution arose because this small island, with only 40 acres of arable land, has supported a relatively large population of around 200 inhabitants at least since the Iron Age. The island could sustain such a population only because the inhabitants acquired their protein from massive exploitation of seabird colonies. The accretion of human waste streams over the millennia has resulted in the polluted soil. Very far from paradise. Andy Meharg is in the School of Biological Sciences, University of Aberdeen, CruickshankBuilding, Aberdeen AB243UU, UK.

apparent love and loyalty of dogs. For the dogs, however, anthropomorphic intervention such as the docking of tails cannot be condoned, he argues.

Thinking with Animals is an unusual book that will surely join the growing literature on consciousness, animal cognition and the continuity between human and animal minds.

Juliet Clutton-Brock, South Barn, High Street,

Fen Ditton, Cambridgeshire CB5 8ST, UK. 